\title{
ANALISIS KONTRIBUSI ALOKASI DANA PENDIDIKAN TERHADAP PROGRAM PENINGKATAN MUTU PENDIDIKAN ANAK USIA DINI (PAUD) PADA DINAS PENDIDIKAN KABUPATEN KEBUMEN
}

\author{
Kardianto Indra Purnomo \\ Politeknik Dharma Patria Kebumen \\ kipurnomo@gmail.com
}

\begin{abstract}
Abstrak
Penelitian ini bermaksud mengetauhi seberapa besar kontribusi alokasi dana pendidikan terhadap program peningkatan mutu pendidikan anak usia dini (PAUD). Hal ini didasari bahwa program peningkatan mutu PAUD berkaitan erat dengan alokasi dana yang diberikan. Bertitik tolak dari permasalahan diatas, maka yang menjadi tujuan penelitian ini adalah mengetahui seberapa besar kontribusi serta efektifitas alokasi dana pendidikan terhadap program peningktaan mutu PAUD. Metode penelitian yang digunakan yaitu metode penelitian deskriptif dengan pendekatan kuantitatif, sedangkan metode pengumpulan data yang digunakan adalah observasi, kuesioner dan dokumentasi. Dari hasil penelitian dapat disimpulkan bahwa kontribusi alokasi dana pendidikan terhadap program peningktan mutu PAUD termasuk dalam kategori sedang (cukup) dengan jumlah prosentase $46,69 \%$ setiap tahunnya. Sedangkan efektifitas program peningkatan mutu PAUD dengan jumlah prosentase $82,6 \%$ artinya termasuk dalam kategori sangat efektif.
\end{abstract}

Kata kunci : Kontribusi, efektifitas, alokasi dana pendidikan, program peningkatan mutu PAUD

\begin{abstract}
This research intends to know how much contribution of funding allocation to the program improving quality of early childhood education. This is based on the program of improving quality of early childhood education is closely related to the allocation of funds provided. Starting from the problems, the purpose of this research are to know how much contribution and effectiveness of funding allocation to the program improving quality of early childhood education. The method used in this research is descriptive research method with quantitative approach. While the data collection method used are observation, questionnaire and documentation. The result of this reseach concluded that contribution of funding allocation to the program improving quality of early childhood education included in the medium (enough) category with the percentage of 46,69\% each year. While the effectiveness of the quality improvement program of early childhood with the percentage of $82,6 \%$ included in the very effective category.
\end{abstract}

Keywords : Contribution, effectiveness, allocation of education funds, program of improving the quality of early childhood education.

\section{A. PENDAHULUAN}

\section{Latar Belakang Masalah}

Pendidikan adalah usaha sadar dan terencana untuk mewujudkan suasana belajar dan proses pembelajaran agar peserta didik secara aktif mengembangkan potensi dirinya untuk memiliki kekuatan spiritual keagamaan, pengendalian diri, kepribadian, kecerdasan, akhlak mulia, serta keterampilan yang diperlukan dirinya, masyarakat, bangsa dan negara. Menurut UU no 20 tahun 2003 tentang sisdiknas, jalur pendidikan di Indonesia terdiri atas pendidikan formal, nonformal, dan informal yang dapat saling melengkapi dan memperkaya.

Jalur pendidikan formal merupakan pendidikan yang diselenggarakan di sekolah-sekolah pada umumya, sedangkan pendidikan nonformal adalah jalur pendidikan diluar pendidikan formal yang dilaksanakan secara terstruktur dan berjenjang. Adapula pendidikan informal yaitu pendidikan keluarga dan lingkungan berbentuk kegiatan belajar secara mandiri yang dilakukan secara sadar dan penuh tanggung jawab.

Jumlah lembaga pendidikan nonformal memang tidak sebanyak pendidikan formal, namun pada dasarnya pendidikan nonformal sangat berperan penting dalam meningkatkan kesejahteraan masyarakat, penanggulangan pengangguran juga peningkatan kualitas sumber daya manusia. Tidak bisa dipungkiri bahwa 
pendidikan anak usia dini merupakan pendidikan yang sangat mendasar dan strategis dalam pembangunan sumber daya manusia. Hadirnya Pendidikan Anak Usia Dini (PAUD) di tengah masyarakat memberi dampak yang positif bagi masyarakat, khususnya bagi tumbuh kembang anak usia dini. Masyarakat merasa terbantu dalam mengasuh dan mendidik anak-anaknya. Prinsip PAUD "bermain sambil belajar" sangat membantu dalam pemberian rangsangan bagi anak.

Setiap unit kerja selalu berhubungan dengan keuangan dalam keberlangsungan kegiatannya, begitu pula dengan Lembaga PAUD. Pembiyaan pendidikan merupakan salah satu aspek penting dalam penyelenggaraan PAUD secara keseluruhan. Pada dasarnya setiap sekolah sudah menyelenggarakan sisitem pengelolaan yang baik, tetapi sistem yang efektif kurang dilaksanakan. Ketidakdisiplinan dalam penggunaan anggaran, minimnya pengetahuan pengelola PAUD dan masyarakat akan standar manajemen PAUD menghasilkan pengelolaan kurang optimal. Untuk itu diperlukan kepemimpinan dan manajemen penngelolaan yang efektif menuju keseimbangan antara sistem yang ada dalam mendistribusikan sumber-sumber dana dan mengembangkan PAUD.

Sumber-sumber pembiayaan pendidikan secara makro telah diatur dalam pasal 31 UUD 1945 yang mengamanatkan pemerintah pusat dan daerah bertanggung jawab menyediakan anggaran pendidikan. Dipertegas lagi oleh Undang-undang Sistem Pendidikan Nasional (UUSPN Tahun 2003) pasal 49 ayat (2) yang menyatakan bahwa: "Dana pendidikan selain gaji pendidik dan biaya pendidikan kedinasan dialokasikan minimal 20\% dari Anggaran Pendapatan dan Belanja Negara (APBN) pada sektor pendidikan dan minimal $20 \%$ dari Anggaran Pendapatan dan Belanja Daerah (APBD)". Dana APBN digunakan untuk Bantuan Operasional Sekolah (BOS) yang setiap daerah mendapatkan jatah yang sama dan APBD digunakan untuk Bantuan Operasional Pembangunan (BOP).

Pendanaan pendidikan merupakan salah satu aspek penting dalam penyelenggaraan berbagai program yang relevan dengan peningkatan mutu SDM. Penyediaan sumber daya keuangan ini diperlukan untuk menjamin terlaksananya berbagai program dan kegiatan dalam mewujudkan tujuan pendidikan. Baik tujuantujuan yang bersifat kualitatif maupun kuantitatif, biaya pendidikan mempunyai peranan yang menentukan, dan menjadi tanggung jawab pemerintah dan masyarakat secara bersamaan.

\section{Pokok Permasalahan}

Berdasakan latar belakang yang telah diuraikan di atas, maka penulis mengambil pokok permasalahan sebagai berikut "seberapa besar kontribusi alokasi dana pendidikan terhadap program peningkatan mutu pendidikan anak usia dini (PAUD) di Dinas Pendidikan Kabupaten Kebumen?

\section{Tujuan Penelitian}

Tujuan dalam penelitian ini adalah :

a. Supaya penulis dan masyarakat tahu berapa persen kontribusi dari alokasi dana pendidikan PAUD terhadap program peningkatan mutu PAUD.

b. Untuk mengetahui apakah kontribusi alokasi dana telah efektif terhadap peningkatan mutu PAUD.

\section{Manfaat Penelitian}

\section{Bagi Instansi :}

1. Dapat dijadikan sebagai bahan masukan dalam menentukan kebijakan peningkatan mutu PAUD di masa yang akan datang.

2. Dapat menjadi pertimbangan untuk diterapkan dalam manajemen pendidikan pada instansi atau lembaga-lembaga pendidikan sebagai upaya meningkatkan PAUD.

3. Meningkatnya persentase kontribusi alokasi dana pendidikan terhadap peningkatan mutu PAUD.

\section{Bagi Penulis :}

1. Menambah pengetahuan dan dapat mempraktekan secara langsung di lapangan pekerjaan nantinya sesuai dengan ilmu yang telah didapat. 
2. Mengerti dan dapat meyelesaikan permasalahan yang ada dalam hal program pendidikan khususnya pendidikan PAUD.

3. Hasil penelitian ini diharapkan dapat menjadi bahan perbandingan atau acuan dalam pengembangan penelitian selanjutnya.

\section{B. KAJIAN TEORITIS}

\section{a. Alokasi Dana Pendidikan}

Alokasi dana pendidikan adalah anggaran keuangan yang diberikan pemerintah kepada lembagalembaga pendidikan. Berdasarkan Undang-Undang Dasar 1945 dan Undang-Undang Nomor 20 Tahun 2003 tentang Sistem Pendidikan Nasional, dana pendidikan selain gaji pendidik dan biaya pendidikan kedinasan mendapat alokasi minimal $20 \%$ dari anggaran pendapatan dan belanja negara dan daerah APBN dan APBD.

b. Pendidikan Anak Usia Dini

Pengertian pendidikan anak usia dini berdasarkan Undang-Undang Nomor 20 Tahun 2003 tentang Sistem Pendidikan Nasional (Sisdiknas), bahwa : Pendidikan anak usia dini (PAUD) adalah suatu upaya pembinaan yang ditujukan kepada anak sejak lahir sampai dengan usia enam tahun yang dilakukan melalui pemberian rangsangan pendidikan untuk membantu pertumbuhan dan perkembangan jasmani dan rohani agar anak memiliki kesiapan dalam memasuki pendidikan lebih lanjut.

\section{c. Program Peningkatan Mutu PAUD}

Dinas Pendidikan Kabupaten Kebumen dalam mewujudkan tujuan pendidikan anak usia dini (PAUD) agar memperoleh pencapaian hasil yang maksimal maka ditetapkan beberapa kegiatan yang tergabung dalam suatu program peningkatan mutu PAUD, sebagai berikut :

1. Penyelenggaraan PAUD

2. Pelatihan kompetensi tenaga pendidik

3. Penyelenggaraan koordinasi dan kerjasama PAUD

4. Pemberian tambahan makanan dan vitamin

d. Analisis Kontribusi dan Efektifitas

Kontribusi adalah sejumlah uang/iuran yang diberikan oleh individu atau kelompok sebagai sebuah bentuk keikutsertaan di dalam sebuah kegiatan ataupun sebagai bentuk sumbangan kepada suatu forum.

Setiap kontribusi yang diberikan diharapkan akan memberikan akibat yang positif, membuat sebuah kemajuan, bukan menurunkan ataupun membuat gagal suatu tujuan yang telah ditentukan.

Efektifitas merupakan hubungan antara output dengan tujuan, semakin besar kontribusi (sumbangan) output terhadap pencapaian tujuan, maka semakin efektif organisasi program atau kegiatan. Penilaian efektifitas suatu program perlu dilakukan untuk mengetahui sejauh mana dampak dan manfaat yang dihasilkan oleh program tersebut. Karena efektifitas merupakan gambaran keberhasilan dalam mencapai sasaran yang telah ditetapkan. Melalui penilaian efektifitas ini dapat menjadi pertimbangan mengenai kelanjutan program tersebut.

\section{METODE}

Metode penelitian yang digunakan yaitu metode penelitian deskriptif dengan pendekatan kuantitatif, sedangkan metode pengumpulan data yang digunakan adalah observasi, kuesioner dan dokumentasi.

1. Menghitung analisis kontribusi penerimaan alokasi dana pendidikan terhadap program peningkatan mutu PAUD melalui progam-program dari Dinas Pendidikan Kabupaten Kebumen.

Rumus Kontribusi :

$\mathrm{Pn}=\frac{\mathrm{QX}}{\mathrm{QY}} \mathrm{X} 100 \%$ 
Keterangan :

Pn : Kontribusi alokasi dana pendidikan terhadap program peningkatan mutu PAUD

QX : Penerimaan Alokasi dana pendidikan

QY : Program peningkatan mutu PAUD

Untuk mengetahui besarnya kontribusi alokasi dana pendidikan terhadap program peningkatan mutu PAUD disusun kriteria sebagai berikut :

$\begin{array}{ll}80 \%-100 \% & =\text { sangat besar } \\ 60 \%-79 \% & =\text { besar } \\ 40 \%-59 \% & =\text { cukup besar } \\ 20 \%-39 \% & =\text { cukup } \\ 0 \%-19 \%=\text { kecil } & \end{array}$

2. Analisis Efektifitas

Dalam proses analisis ini dilakukan dengan membaca tabel-tabel dan teknik deskriptif prosentase. Teknik deskriptif prosentase dimaksudkan untuk mengetahui status sesuatu yang disajikan dalam bentuk prosentase yang dirumuskan sebagai berikut:

Dp $\%=\frac{n}{N} \times 100 \%$

Keterangan :

Dp : Deskriptif prosentase

$\mathrm{n} \quad$ : Jumlah skor masing-masing variabel

$\mathrm{N}$ : Jumlah skor total

Tingkat efektifitas program peningkatan mutu pendidikan PAUD digolongkan menjadi beberapa kriteria sebagai berikut :

$\begin{array}{ll}80 \%-100 \% & =\text { sangat besar } \\ 60 \%-79 \% & =\text { besar } \\ 40 \%-59 \% & =\text { cukup besar } \\ 20 \%-39 \% & =\text { cukup } \\ 0 \%-19 \% & =\text { kecil }\end{array}$

D. HASIL DAN PEMBAHASAN

1. Analisis Kontribusi

Tabel 1 : Target dan Realisasi Alokasi Dana Pendidikan. 


\begin{tabular}{|c|c|c|c|c|c|}
\hline Tahun & Target & Reslis & & Kontribusi. & Rata-Rata \\
\hline \multirow{4}{*}{2014} & \multirow{4}{*}{$\operatorname{Rg} 2,182,900,000$} & $\mathrm{Rp}$ & $2,000,400,000$ & 1,0996 & \multirow{4}{*}{$89,34 \%$} \\
\hline & & $\mathrm{Rg}$ & $45,000,000$ & $48,5 \%$ & \\
\hline & & $\mathrm{Rp}$ & $130,000,000$ & $16,79 \%$ & \\
\hline & & $\mathrm{Rp}$ & $7,500,000$ & $291,05 \%$ & \\
\hline \multirow{3}{*}{2015} & \multirow{3}{*}{$\operatorname{Rg} 2,182,900,000$} & $\mathrm{Rp}$ & $2,000,400,000$ & $1,11 \%$ & \multirow{3}{*}{$22,55 \%$} \\
\hline & & $\mathrm{Rp}$ & $45,000,000$ & $49,45 \%$ & \\
\hline & & $\mathrm{Rg}$ & $180,000,000$ & $17,11 \%$ & \\
\hline \multirow{3}{*}{2016} & \multirow{3}{*}{$\operatorname{Rg} 2,650,400,000$} & $\mathrm{Rg}$ & $2,415,400,000$ & 10,979 & \multirow{3}{*}{$28,19 \%$} \\
\hline & & $\mathrm{Rg}$ & $45,000,000$ & $14,72 \%$ & \\
\hline & & $\mathrm{Rp}$ & $190,000,000$ & $14,72 \%$ & \\
\hline
\end{tabular}

Untuk mengetahui tingkat kontribusi alokasi dana pendidikan terhadap program peningkatan mutu PAUD dapat dilakukan dengan analisis deskriptif prosentase sebagai berikut.

a. Tahun 2014

1) Program Penyelenggaraan PAUD

$$
\begin{aligned}
& =\frac{\operatorname{Rp} 2,182,900,000}{\operatorname{Rp} 2,000,400,000} \times 100 \% \\
& =1.09 \%
\end{aligned}
$$

2) Program Pelatihan Kompetensi Tenaga Pendidik

$$
\begin{aligned}
\text { Pn } & =\frac{\text { Rp2,182,900,000 }}{\text { Rp45,000,000 }} \times 100 \% \\
& =48.5 \%
\end{aligned}
$$

3) Program Penyelenggaraan Koordinasi \& Kerjasama PAUD

$$
\begin{aligned}
\text { Pn } & =\frac{\operatorname{Rp} 2,182,900,000}{\operatorname{Rp} 130,000,000} \times 100 \% \\
& =16.79 \%
\end{aligned}
$$

4) Program Pemberian Tambahan Makanan \& Vitamin

$$
\begin{aligned}
\text { Pn } & =\frac{\operatorname{Rp} 2,182,900,000}{R p 7,500,000} \times 100 \% \\
& =291.05 \%
\end{aligned}
$$

Pada tahun 2014 rata-rata jumlah kontribusi alokasi dana pendidikan terhadap 4 program peningkatan mutu pendidikan adalah :

$$
\begin{aligned}
& =\frac{\text { Jumlah kontribusi alokasi dana tahun } 2014}{\text { Program peningkatan mutu tahun } 2014} \\
& =\frac{357,38 \%}{4}=89,34 \%
\end{aligned}
$$


Jadi, rata-rata kontribusi alokasi dana pendidikan pada tahun 2014 sebesar 89,34\%. Hal tersebut berarti kontribusi alokasi dana pendidikan terhadap program peningkatan mutu PAUD pada tahun 2014 termasuk dalam kategori sangat besar.

b. Tahun 2015

1) Program Penyelenggaraan PAUD

$$
\begin{aligned}
& \text { Pn }=\frac{\text { Rp2,225,400,000 }}{\text { Rp2, } 000,400,000} \quad x 100 \% \\
& =1.11 \%
\end{aligned}
$$

2) Program Pelatihan Kompetensi TenagaPendidik

$$
\begin{aligned}
& \text { Pn }=\frac{\mathrm{Rp} 2,225,400,000}{\mathrm{Rp} 45,000,000} \times 100 \% \\
& =\quad 49.45 \%
\end{aligned}
$$

3) Program Penyelenggaraan Koordinasi \& Kerjasama PAUD

$$
\begin{aligned}
& \operatorname{Pn}=\frac{\mathrm{Rp} 2,225,400,000}{\mathrm{Rp} 130,000,000} \times 100 \% \\
& =17.11 \%
\end{aligned}
$$

Tahun 2015, rata-rata jumlah kontribusi alokasi dana pendidikan terhadap 3 program peningkatan mutu pendidikan adalah :

$$
\begin{aligned}
& =\frac{\text { Jumlah kontribusi alokasi dana tahun } 2015}{\text { Programpeningkatan mutu tahun } 2015} \\
& =\frac{67,67 \%}{3}=22,55 \% .
\end{aligned}
$$

Jadi, rata-rata kontribusi alokasi dana pendidikan pada tahun 2015 sebesar 22,55\%. Hal tersebut berarti kontribusi alokasi dana pendidikan terhadap program peningkatan mutu PAUD pada tahun 2015 termasuk dalam kategori kecil.

c. Tahun 2016

1) Program Penyelenggaraan PAUD

$$
\begin{aligned}
& \text { Pn }=\frac{\text { Rp2 } 2,650,400,000}{\operatorname{Rp} 2,415,400,000} \times 100 \% \\
& =\quad 10.97 \%
\end{aligned}
$$

2) Program Pelatihan Kompetensi TenagaPendidik

$$
\mathrm{Pn}=\frac{\mathrm{Rp} 2,650,400,000}{\mathrm{Rp} 45,000,000} \times 100 \%
$$

$=58.89 \%$

3) Program Penyelenggaraan Koordinasi \& Kerjasama PAUD

$$
\mathrm{Pn}=\frac{\mathrm{Rp} 2,650,400,000}{\mathrm{Rp} 180,000,000} \times 100 \%
$$

$=14.72 \%$

Tahun 2016, rata-rata jumlah kontribusi alokasi dana pendidikan terhadap 3 program peningkatan mutu pendidikan adalah : 


$$
\begin{aligned}
& =\frac{\text { Jumlah kontribusi alokasi dana tahun } 2016}{\text { Program peningkatan mutu tahun } 2016} \\
& =\frac{84,58 \%}{3}=28,19 \%
\end{aligned}
$$

Jadi, rata-rata kontribusi alokasi dana pendidikan pada tahun 2016 sebesar 28,19\%. Hal tersebut berarti kontribusi alokasi dana pendidikan terhadap program peningkatan mutu PAUD pada tahun 2016 termasuk dalam kategori kecil.

Selanjutnya untuk mengetahui rata-rata kontribusi alokasi dana pendidikan terhadap program peningkatan mutu PAUD di setiap tahun anggaran, maka :

$$
\begin{aligned}
& =\frac{\text { Jumlah kontribusi Alokasi dana pendidikan selama } 3 \text { tahun }}{3 \text { Tahun angegaran }} \\
& =\frac{140,09 \%}{3}=46,69 \%
\end{aligned}
$$

Dari hasil analisis di atas dapat dilihat bahwa kontribusi alokasi dana pendidikan terhadap program peningkatan mutu PAUD masih berada dalam kategori sedang yaitu dalam rentang 40\%-59\%. Hal tersebut berarti bahwa alokasi dana pendidikan memiliki andil yang cukup dalam pencapaian hasil program peningkatan mutu PAUD.

\section{Analisis Efektifitas}

Untuk mengetahui tingkat efektifitas program-program peningkatan mutu PAUD dapat dilakukan dengan analisis deskriptif prosentase yang digunakan untuk memberikan gambaran mengenai hasil penelitian dengan membandingkan hasil penelitian tersebut dengan kondisi maksimal yang diperoleh.

Hasil jawaban dari 15 responden terhadap item-item kuesioner yang terdiri dari 30 pertanyaan yang terbagi dalam 4 faktor memberikan hasil sebagai berikut ini.

a. Program Penyelenggaraan PAUD

Program penyelenggaraan PAUD ini terdiri dari 12 item pertanyaan. Jumlah skor untuk ke 12 item tersebut adalah sebesar 602. Skor jawaban maksimal yang mungkin diperoleh untuk pertanyaan terhadap program penyelenggaraan PAUD ini adalah 780. Dengan demikian, deskriptif prosentase dari program penyelenggaraan PAUD diperoleh sebesar 79,6\%.

Hasil tersebut menunjukkan bahwa tanggapan responden terhadap program penyelenggaraan PAUD adalah sebesar 79,6\% dari kondisi idealnya. Hal tersebut berarti program penyelenggaraan PAUD masuk dalam kategori efektif.

b. Program Pelatihan Kompetensi Tenaga Pendidik

Program pelatihan kompetensi tenaga pendidik terdiri dari 7 item pertanyaan. Jumlah skor untuk ke 7 item tersebut adalah sebesar 348. Skor jawaban maksimal yang mungkin diperoleh untuk pertanyaan terhadap program pelatihan kompetensi tenaga pendidik ini adalah 420. Dengan demikian, deskriptif prosentase dari program pelatihan kompetensi tenaga pendidik diperoleh sebesar $83 \%$.

Hasil tersebut menunjukkan bahwa tanggapan responden terhadap program pelatihan kompetensi tenaga pendidik adalah sebesar $83 \%$ dari kondisi idealnya. Hal tersebut berarti program pelatihan kompetensi tenaga pendidik masuk dalam kategori sangat efektif.

c. Program Penyelenggaraan Koordinasi dan Kerjasama PAUD

Program penyelenggaraan koordinasi dan kerjasama PAUD terdiri dari 4 item pertanyaan. Jumlah skor untuk ke 4 item tersebut adalah sebesar 147. Skor jawaban maksimal 
yang mungkin diperoleh untuk pertanyaan terhadap program penyelenggaraan koordinasi dan kerjasama PAUD ini adalah 180. Dengan demikian, deskriptif prosentase dari program penyelenggaraan koordinasi dan kerjasama PAUD diperoleh sebesar $82 \%$.

Hasil tersebut menunjukkan bahwa tanggapan responden terhadap program penyelenggaraan koordinasi dan kerjasama PAUD adalah sebesar $82 \%$ dari kondisi idealnya. Hal tersebut berarti program penyelenggaraan PAUD masuk dalam kategori sangat efektif.

d. Program Pemberian Tambahan Makanan dan Vitamin

Program pemberian tambahan makanan dan vitamin terdiri dari 2 item pertanyaan. Jumlah skor untuk ke 2 item tersebut adalah sebesar 97. Skor jawaban maksimal yang mungkin diperoleh untuk pertanyaan terhadap program pemberian tambahan makanan dan vitamin ini adalah 120. Dengan demikian, deskriptif prosentase dari program pemberian tambahan makanan dan vitamin diperoleh sebesar $81 \%$.

Hasil tersebut menunjukkan bahwa tanggapan responden terhadap program pemberian tambahan makanan dan vitamin adalah sebesar $81 \%$ dari kondisi idealnya. Hal tersebut berarti pemberian tambahan makanan dan vitamin masuk dalam kategori sangat efektif.

Berdasarkan data-data yang diuraikan di atas maka dapat diperoleh gambaran efektifitas program peningkatan mutu PAUD yang meliputi 4 macam yaitu program penyelenggaraan PAUD, program pelatihan kompetensi teanga pendidik, program penyelenggaraan koordinasi dan kerjasama PAUD dan program pemberian tambahan makanan dan vitamin. Dari data tersebut dapat rekapitulasi masing-masing komponen dari ke-15 responden sebagaimana terlihat pada tabel berikut:

Tabel 2 : Rekapitulasi Program Peningkatan Mutu PAUD

\begin{tabular}{|c|c|c|c|}
\hline No & $\begin{array}{c}\text { Program Peningkatan } \\
\text { Mutu PAUD }\end{array}$ & $\begin{array}{c}\text { Jumlah Skor } \\
\text { masing-masing } \\
\text { aspek }\end{array}$ & $\begin{array}{c}\text { Jumlah Skor } \\
\text { Maksimal }\end{array}$ \\
\hline 1 & Penyelenggaraan PAUD & 602 & 780 \\
\hline 2 & $\begin{array}{l}\text { Pelatihan Kompetensi } \\
\text { Tenaga Pendidik }\end{array}$ & 348 & 420 \\
\hline 3 & $\begin{array}{l}\text { Penyelenggaraan } \\
\text { Koordinasi \& Kerjasama } \\
\text { PAUD }\end{array}$ & 147 & 180 \\
\hline \multirow[t]{2}{*}{4} & $\begin{array}{l}\text { Pemberian Tambahan } \\
\text { Makanan \& Vitamin }\end{array}$ & 97 & 120 \\
\hline & Jumlah & 1194 & 1500 \\
\hline
\end{tabular}

Sumber: Hasil Perhitungan Jawaban Responden

Berdasarkan hasil analisa deskriptif prosentase di atas jika dari program pelatihan kompetensi tenaga pendidik diperoleh sebesar $83 \%$.

Hasil tersebut menunjukkan bahwa tanggapan responden terhadap program pelatihan kompetensi tenaga pendidik adalah sebesar $83 \%$ dari kondisi idealnya. Hal tersebut berarti program pelatihan kompetensi tenaga pendidik masuk dalam kategori sangat efektif.

a. Program Penyelenggaraan Koordinasi dan Kerjasama PAUD

Program penyelenggaraan koordinasi dan kerjasama PAUD terdiri dari 4 item pertanyaan. Jumlah skor untuk ke 4 item tersebut adalah sebesar 147. Skor jawaban maksimal yang mungkin diperoleh untuk pertanyaan terhadap program penyelenggaraan koordinasi dan kerjasama PAUD ini adalah 180. Dengan demikian, deskriptif prosentase dari program penyelenggaraan koordinasi dan kerjasama PAUD diperoleh sebesar 82\%.

Hasil tersebut menunjukkan bahwa tanggapan responden terhadap program penyelenggaraan koordinasi dan kerjasama PAUD adalah sebesar $82 \%$ dari kondisi 
idealnya. Hal tersebut berarti program penyelenggaraan PAUD masuk dalam kategori sangat efektif.

b. Program Pemberian Tambahan Makanan dan Vitamin

Program pemberian tambahan makanan dan vitamin terdiri dari 2 item pertanyaan. Jumlah skor untuk ke 2 item tersebut adalah sebesar 97. Skor jawaban maksimal yang mungkin diperoleh untuk pertanyaan terhadap program pemberian tambahan makanan dan vitamin ini adalah 120. Dengan demikian, deskriptif prosentase dari program pemberian tambahan makanan dan vitamin diperoleh sebesar $81 \%$.

Hasil tersebut menunjukkan bahwa tanggapan responden terhadap program pemberian tambahan makanan dan vitamin adalah sebesar $81 \%$ dari kondisi idealnya. Hal tersebut berarti pemberian tambahan makanan dan vitamin masuk dalam kategori sangat efektif.

Berdasarkan data-data yang diuraikan di atas maka dapat diperoleh gambaran efektifitas program peningkatan mutu PAUD yang meliputi 4 macam yaitu program penyelenggaraan PAUD, program pelatihan kompetensi teanga pendidik, program penyelenggaraan koordinasi dan kerjasama PAUD dan program pemberian tambahan makanan dan vitamin. Dari data tersebut dapat rekapitulasi masing-masing komponen dari ke-15 responden sebagaimana terlihat pada tabel berikut:

Tabel 2 : Rekapitulasi Program Peningkatan Mutu PAUD

\begin{tabular}{|c|l|c|c|}
\hline No & \multicolumn{1}{|c|}{$\begin{array}{c}\text { Program Peningkatan } \\
\text { Mutu PAUD }\end{array}$} & $\begin{array}{c}\text { Jumlah Skor } \\
\text { masing-masing } \\
\text { aspek }\end{array}$ & $\begin{array}{c}\text { Jumlah Skor } \\
\text { Maksimal }\end{array}$ \\
\hline 1 & Penyelenggaraan PAUD & 602 & 780 \\
\hline 2 & $\begin{array}{l}\text { Pelatihan Kompetensi } \\
\text { Tenaga Pendidik }\end{array}$ & 348 & 420 \\
\hline 3 & $\begin{array}{l}\text { Penyelenggaraan } \\
\text { Koordinasi \& Kerjasama } \\
\text { PAUD }\end{array}$ & 147 & 180 \\
\hline 4 & $\begin{array}{l}\text { Pemberian Tambahan } \\
\text { Makanan \& Vitamin }\end{array}$ & 97 & 120 \\
\hline & Jumlah & 1194 & 1500 \\
\hline
\end{tabular}

Sumber: Hasil Perhitungan Jawaban Responden

Berdasarkan hasil analisa deskriptif prosentase di atas jika dikonsultasikan dengan tabel kriteria efektifitas program peningkatan mutu PAUD dengan jumlah skor 1194 dan nilai maksimal 1500 yang diproses perhitungan nilai 79,6\% termasuk dalam kategori efektif.

\section{Permasalahan yang Dihadapi}

Pelaksanaan program peningkatan mutu PAUD berhubungan erat dengan alokasi dana pendidikan maka peneliti ingin melakukan penelitian mengenai seberapa besar kontribusi alokasi dana pendidikan serta seberapa efektifitas terhadap program peningkatan mutu PAUD dengan meggunakan analisis kontribusi dan efektifitas.

\section{Upaya Untuk Mengatasi Permasalahan}

Untuk mengetahui seberapa besar kontribusi alokasi dana pendidikan serta efektifitas terhadap program peningkatan mutu PAUD pada Dinas Pendidikan dapat menggunakan analisis kontribusi dan efektifitas yang merupakan metode yang perhitungannya lebih nyata dengan keadaan dan Penelitian ini dapat menjadi bahan pertimbangan untuk ketetapan kebijakan pemerintah khususnya Dinas Pendidikan dalam membuat suatu kebijakan mengenai peningkatan kontribusi serta efektifitas alokasi dana pendidikan terhadap program peningkatan mutu pendidikan anak usia dini (PAUD). 


\section{E. PENUTUP}

\section{Kesimpulan}

Dari hasil analisis terhadap kontribusi alokasi dana pendidikan terhadap program peningkatan mutu pendidikan PAUD pada Dinas Pendidikan Kabupaten Kebumen dapat disimpulkan bahwa :

a. Kontribusi alokasi dana pendidikan terhadap program peningkatan mutu pendidikan anak usia dini (PAUD) termasuk dalam kategori sedang, yang artinya cukup memberikan andil dalam peningkatan mutu pendidikan anak usia dini dengan prosentase 46,69\%. Hal tersebut disimpulkan dari hasil peelitian sebagai berikut:

1) Tahun 2014

Rata-rata kontribusi alokasi dana pendidikan pada tahun 2014 sebesar 89,34\%, terdiri dari program penyelenggaraan PAUD diperoleh skor 1,09\%, program pelatihan kompetensi tenaga pendidik diperoleh skor 48,5\%, program penyelenggaraan koordinasi dan kerjasama PAUD diperoleh skor $16,79 \%$, program pemberian tambahan makanan dan vitamin diperoleh skor $291 \%$.

2) Tahun 2015

b. Rata-rata kontribusi alokasi dana pendidikan pada tahun 2015 sebesar $22,55 \%$, terdiri dari program penyelenggaraan PAUD diperoleh skor 1,11\%, program pelatihan kompetensi tenaga pendidik diperoleh skor 49,45\%, program penyelenggaraan koordinasi dan kerjasama PAUD diperoleh skor $17,11 \%$. Efektifitas program peningkatan mutu PAUD termasuk dalam kategori sangat efektif dengan prosentase $82,6 \%$. Hal tersebut disimpulkan dari hasil penelitian sebagai berikut :

1. Program penyelenggaraan PAUD diperoleh hasil prosentase sebesar $83 \%$.

2. Program pelatihan kompetensi tenaga pendidik diperoleh hasil prosentase sebesar $83 \%$.

3. Program peyelenggaraan koordinasi dan kerjasama PAUD diperoleh hasil prosentase sebesar $82 \%$.

4. Program pemberian tambahan makanan dan vitamin diperoleh hasil prosentase sebesar $81 \%$.

\section{Saran}

Dengan hasil penelitian yang dijelaskan di muka, maka agar menigkatkan kontribusi alokasi dana dan efektifitas program peningkatan mutu PAUD berjalan dengan baik perlu beberapa upaya sebagai berikut :

a. Diharapkan Dinas Pendidikan Kabupaten Kebumen lebih giat mengadakan sosialisasi kepada para pengelola lembaga PAUD akan pentingnya program-program peningkatan mutu PAUD yang telah ditetapkan oleh Dinas Pendidikan.

b. Agar realisasi program peningkatan mutu PAUD dapat mencapai hasil yang maksimal, Dinas Pendidikan Kabupaten Kebumen hendaknya meningkatkan standar pencapaian pada programprogram yang telah dijalankan.

c. Hendaknya Dinas Pendidikan Kabupaten Kebumen lebih rutin melakukan monitoring langsung secara menyeluruh ke lapangan mengenai realisasi alokasi dana pendidikan yang telah diberikan kepada lembaga PAUD, bukan hanya dengan laporan tertulis.

\section{F. DAFTAR PUSTAKA}

Peraturan Daerah Kabupaten Kebumen Nomor 7 Tahun 2016 tentang Pembentukan Dan Susunan Perangkat Daerah Kabupaten Kebumen, dan Perubahan Sruktur Organisasi Dan Tata Kerja.

Perbup Kabupaten Kebumen Nomor 66 Tahun 2016 tentang Kedudukan, Susunan Organisasi, Tugas Dan Fungsi, Serta Tata Kerja Dinas Pendidikan Kabupaten Kebumen. 
Undang-Undang Republik Indonesia Nomor 20 Tahun 2003 tentang Sistem Pendidikan Nasional.

Abdul, Hadis dan Nurhayati. 2010. Manajemen Mutu Pendidikan. Bandung: Alfabeta.

Aditya, Bayu. 2016. Analisis Kontribusi Bea Perolehan Hak Atas Tanah dan Pajak Reklame Terhadap Pendapatan Asli Daerah di DPPKAD Kabupaten Kebumen. Program Studi Akuntansi Politeknik DharmaPatria Kebumen.

Cynthia. N, Pindo. 2009. Efektifitas Pengelolaan Program Pendiidkan Anak Usia Dini (PAUD) di Playgroup “ANNISA” Pekajangan Kabupaten Pekalongan. Jurusan Pendidikan Luar 
Hasan, Erliana. 2011. Filsafat Ilmu dan Metodologi Ilmu Pemerintahan. Bandung: Galia Indonesia.

H.S. Rahman. 2002. Konsep Dasar Pendidikan Anak Usia Dini. Yogyakarta: PGTKI Press.

Soegeng Santoso. 2002. Pendidikan Anak Usia Dini. Jakarta: Citra Pendidikan.

Sugiyono. 2012. Metode Penelitian Kuantitatif, Kualitatif, dan R\&D. Bandung: Alfabeta. 